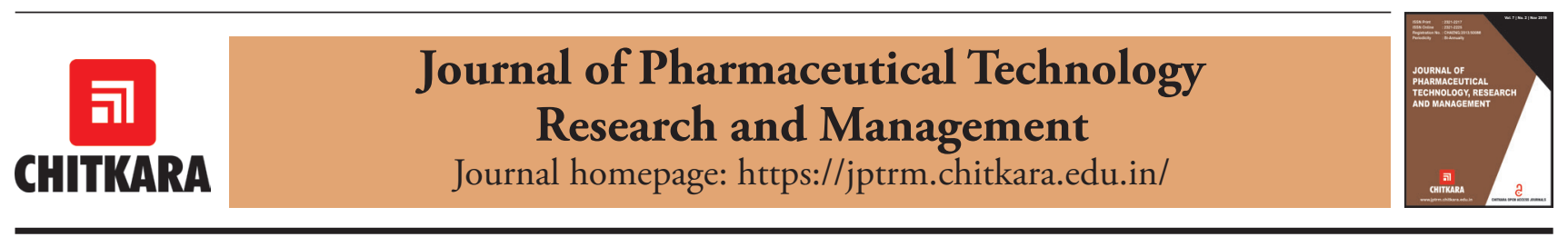

\title{
Ranitidine Induced Hepatotoxicity: A Review
}

\author{
Amit Bandyopadhyay Banerjee ${ }^{1}$, Manisha Gupta ${ }^{2}$, Thakur Gurjeet Singh ${ }^{3}$, Sandeep Arora ${ }^{4}$ and Onkar Bedi ${ }^{* *}$ \\ Chitkara College of Pharmacy, Chitkara University, Punjab-140401, India \\ 'banerjee809amit@gmail.com \\ 2im.manishagupta1446@gmail.com \\ ${ }^{3}$ gurjeetthakur@gmail.com \\ ${ }^{4}$ sandeep.arora@chitkara.edu.in \\ 5*onkar.bedi@chitkara.edu.in (Corresponding Author)
}

\section{ARTICLE INFORMATION}

Received: January 29, 2020

Revised: April 08, 2020

Accepted: April 28, 2020

Published Online: May 20, 2020

Keywords:

DILI, Ranitidine withdrawal, RAN induced

hepatotoxicity

\begin{abstract}
Background: Ranitidine (RAN) is one of the common drugs associated with idiosyncratic adverse drug reactions (IADRs) in humans. It was found to be associated with severe adverse drug reactions due to the presence of contaminants such as N-Nitrosodimethylamine (NDMA) which is claimed to be carcinogenic. As a consequence, on April 1, 2020, United States Food and Drug Administration (USFDA) had decided to call off all the RAN products from the market. The exact cause of RAN associated idiosyncratic hepatotoxicity is not clear yet.

Purpose: To summarize and analyze the reason behind the withdrawal of RAN products from the market and whether ranitidine will be available again in future or will FDA withdraw approvals of ranitidine National Drug Authority (NDA) and an abbreviated new drug application (ANDA)? Methods: We performed a systematic PubMed/MEDLINE search of studies investigating the reason behind the withdrawal of RAN products and explored the possible mechanism associated with RAN induced hepatotoxicity.

Conclusion: RAN induced liver injury is difficult to diagnose and study because of its relative rarity and unpredictive occurrence. Recent studies suggest that most of the RAN associated idiosyncratic reactions may lead to hepatocyte damage, followed by a series of events, such as activation of specific T- and B-cells, release of proinflammatory mediators like TNF $\alpha$, interleukins, various cytokines and chemokines. The exact cause of RAN associated idiosyncratic hepatotoxicity is not clear yet. More studies must be carried out on this to know about the exact reason behind RAN associated hepatotoxicity.
\end{abstract}

\section{Introduction}

Drug induced liver injury (DILI) is a primary safety concern during drug discovery and those drugs which are found to be associated with severe adverse drug reactions (ADRs) are mainly withdrawn from the market. There are few drugs which have been withdrawn due to its severe ADRs reported over the period of time in the post-marketing surveillance (PMS) [summarized in Table 1] and Ranitidine (RAN) is one of them and it is found to be associated with idiosyncratic hepatotoxic reactions (Teschke et al., 2018). RAN is widely used in the treatment of gastrointestinal diseases and is one of the most frequently prescribed drugs worldwide (Chalasani et al., 2010). An estimated $34.2 \pm 10.7$ cases of DILI per 1 million people per year were reported in the Spanish DILI Registry. It has been observed that, amongst all the DILI cases about $53 \%$ had to be hospitalized, $2 \%$ undergone liver transplant, $10 \%$ and $5 \%$ had a chronic liver disease and acute liver disease respectively (Andrade et al., 2005). DILI is a major reason behind the withdrawal of various pharmaceutical products. RAN induced liver injury may be an associated factor for its withdrawal from pharmaceutical market (Kaplowitz et al., 2005). Based on its clinical characteristics, RAN induced hepatotoxicity can be classified as cholestatic (mainly an increase in alkaline phosphatase, ALP), hepatocellular (primarily an increase in alanine aminotransferase, ALT) and mixed hepatotoxicity depending upon the type of observed liver injury. 
Table 1: List of drugs called off due to hepatotoxicity worldwide.

\begin{tabular}{|c|c|c|c|c|c|}
\hline S. No. & Drug name & Withdrawn & Country & Remarks & Reference \\
\hline 1. & Xenazoic acid & 1965 & France & Hepatotoxicity & Fung et al., 2001 \\
\hline 2. & Phenoxypropazine & 1966 & UK & Hepatotoxicity, drug interaction & Fung et al., 2001 \\
\hline 3. & Ibufenac & 1968 & UK & Hepatotoxcity & Fung et al., 2001 \\
\hline 4. & Fenclozic acid & 1970 & UK, US & Hepatotoxicty & Fung et al., 2001 \\
\hline 5. & Diacetoxydiphenolisatin & 1971 & Australia & Hepatotoxicity & Fung et al., 2001 \\
\hline 6. & Triacetyldiphenolisatin & 1971 & Australia & Hepatotoxicity & Fung et al., 2001 \\
\hline 7. & Nialamide & 1974 & UK, US & Hepatotoxicity, drug interaction & Fung et al., 2001 \\
\hline 8. & Mebanazine & 1975 & UK & Hepatotoxicity, drug interaction & Fung et al., 2001 \\
\hline 9. & Ticrynafen (Tienilic acid) & 1980 & $\begin{array}{l}\text { Germany, UK, } \\
\text { US, France }\end{array}$ & Liver toxicity and death. & Fung et al., 2001 \\
\hline 10. & Benoxaprofen & 1982 & $\begin{array}{l}\text { Germany, } \\
\text { Spain, US, UK }\end{array}$ & $\begin{array}{l}\text { Liver and kidney failure; } \\
\text { gastrointestinal bleeding; ulcers. }\end{array}$ & $\begin{array}{l}\text { Qureshi et al., 2011; Fung } \\
\text { et al., } 2001\end{array}$ \\
\hline 11. & Clomacron & 1982 & UK & Hepatotoxicty & Fung et al., 2001 \\
\hline 12. & Zimelidine & 1983 & Worldwide & Hepatotoxicty & $\begin{array}{l}\text { Fung et al., 2001; Fagius } \\
\text { et al., } 1985\end{array}$ \\
\hline 13. & Isaxonine phosphate & 1984 & France & Hepatotoxcity & Fung et al., 2001 \\
\hline 14. & Clometacin & 1987 & France & Hepatotoxicty & Fung et al., 2001 \\
\hline 15. & Cyclofenil & 1987 & France & Hepatotoxicity & Fung et al., 2001 \\
\hline 16. & Exifone & 1989 & France & Hepatotoxicty & Fung et al., 2001 \\
\hline 17. & Pirprofen & 1990 & $\begin{array}{l}\text { France, Spain, } \\
\text { Germany }\end{array}$ & Liver toxicity & Fung et al., 2001 \\
\hline 18. & Dilevalol & 1990 & UK & Hepatotoxicty & Fung et al., 2001 \\
\hline 19. & Fipexide & 1991 & France & Hepatotoxicty & Fung et al., 2001 \\
\hline 20. & Bendazac & 1993 & Spain & Hepatotoxicity & Fung et al., 2001 \\
\hline 21. & Alpidem (Ananxyl) & 1995 & Worldwide & $\begin{array}{l}\text { Not approved in US, withdrawan } \\
\text { in France in } 1994 \text { and the rest of } \\
\text { the market in } 1995 \text { because of } \\
\text { rare but serious hepatotoxicity. }\end{array}$ & $\begin{array}{l}\text { Fung et al., 2001; Berson } \\
\text { et al., } 2001\end{array}$ \\
\hline 22. & $\begin{array}{l}\text { Chlormezanone } \\
\text { (Trancopal) }\end{array}$ & 1996 & $\begin{array}{l}\text { European } \\
\text { Union, US, } \\
\text { South Africa, } \\
\text { Japan } \\
\end{array}$ & $\begin{array}{l}\text { Hepatotoxicity \& Steven-Johnson } \\
\text { Syndrome }\end{array}$ & Fung et al., 2001 \\
\hline 23. & Tolrestat (Alredase) & 1996 & $\begin{array}{l}\text { Argentina, } \\
\text { Canada, Italy, } \\
\text { others }\end{array}$ & Severe form of hepatotoxicity & Fung et al., 2001 \\
\hline 24. & Pemoline (Cylert) & 1997 & Canada, UK & $\begin{array}{l}\text { Withdrawn from US in } 2005 . \\
\text { Hepatotoxicity }\end{array}$ & Drug Bank website \\
\hline 25. & Ebrotidine & 1998 & Spain & Hepatotoxicty & Fung et al., 2001 \\
\hline 26. & Tolcapone (Tasmar) & 1998 & $\begin{array}{l}\text { European } \\
\text { Union, } \\
\text { Australia, } \\
\text { Canada } \\
\end{array}$ & Hepatotoxicty & Fung et al., 2001 \\
\hline 27. & Troglitazone (Rezulin) & 2000 & Germany, US & Hepatotoxicity & Qureshi et al., 2011 \\
\hline 28. & Kava Kava & 2002 & Germany & Hepatotoxicity & Schubert-Zsilavecz, 2011 \\
\hline
\end{tabular}




\begin{tabular}{|l|l|l|l|l|l|}
\hline 29. & Alatrofloxacin & 2006 & Worldwide & $\begin{array}{l}\text { Serious liver injury leading to liver } \\
\text { transplant or death. }\end{array}$ & Qureshi et al., 2011 \\
\hline 30. & Ximelagatran (Exanta) & 2006 & Germany & Hepatotoxicity & Schubert-Zsilavecz, 2011 \\
\hline 31. & Lumiracoxib (Prexige) & $2007-2008$ & Worldwide & Liver damage & Qureshi et al., 2011 \\
\hline 32. & Sitaxentan & 2010 & Germany & Hepatotoxicity & Schubert-Zsilavecz, 2011 \\
\hline 33. & Flupirtine & 2018 & $\begin{array}{l}\text { European } \\
\text { Union }\end{array}$ & Liver toxicity & $\begin{array}{l}\text { European Medicines } \\
\text { Agency, 2018 }\end{array}$ \\
\hline 34. & Ranitidine & 2020 & US & $\begin{array}{l}\text { Hepatotoxicity, idiosyncratic } \\
\text { hepatotoxic reactions }\end{array}$ & Shaik et al., 2020 \\
\hline 35. & $\begin{array}{l}\text { Oxyphenisatin } \\
\text { (Phenisatin) }\end{array}$ & $\begin{array}{l}\text { Australia, } \\
\text { France, } \\
\text { Germany, UK, } \\
\text { US }\end{array}$ & Hepatotoxicity & Fung et al., 2001 & \\
\hline
\end{tabular}

Scientific data showed that there are numerous drugs, such as Ranitidine, Cimetidine and Famotidine, which are responsible for induction of hepatotoxicity. Hepatic cellular dysfunction initiates various immunological reactions such as innate and adaptive immune responses. Stress and/or damage to the hepatocytes may trigger the activation of Kupffer cells (KC), natural killer cells (NK) and natural killer T (NKT) cells which enhance the release of various pro-inflammatory mediators and chemokines in the liver (Blazka et al., 1995; Blazka et al., 1996; Ishida et al., 2002). Although, RAN induced liver injury subsides after the termination of drug treatment, still it is a major diagnostic and therapeutic concern for doctors. Majority of RAN associated liver injury cases are not recognized during clinical trials, later on they are reported in post marketing surveillance. There is a lack of preclinical and clinical studies on ranitidine, but there are some case studies [summarized in Table 2] which evidenced that ranitidine therapy raises the risk of liver disorders (Alfirevic et al., 2012). The present review focuses on the possible mechanism behind the etiology of RAN induced liver toxicity and reason behind the withdrawal of RAN from the market.

Table 2: Case study reports on ranitidine therapy.

\begin{tabular}{|c|c|c|c|c|c|c|c|}
\hline $\begin{array}{l}\text { S. } \\
\text { No. }\end{array}$ & Case study & $\begin{array}{l}\text { Ranitidine } \\
\text { therapy }\end{array}$ & Observation & \begin{tabular}{|l} 
Pathological \\
outcomes
\end{tabular} & Latency & Recovery & Reference \\
\hline 1. & $\begin{array}{l}\text { 63-year-old woman } \\
\text { with duodenal ulcer }\end{array}$ & $\begin{array}{l}150 \mathrm{mg} \\
\text { twice daily }\end{array}$ & $\begin{array}{l}\text { Elevated serum aminotransferase levels } \\
\text { (ALT, AST,GGT) }\end{array}$ & $\begin{array}{l}\text { anicteric } \\
\text { hepatitis }\end{array}$ & 2 weeks & 10 days & $\begin{array}{l}\text { (Barr et al., } \\
1981)\end{array}$ \\
\hline 2. & 66 year old & $\begin{array}{l}150 \mathrm{mg} \\
\text { daily }\end{array}$ & $\begin{array}{l}\text { mild focal necrosis, with moderate portal } \\
\text { inflammation and mild cholestasis (ALT } \\
\text { and ALK P) }\end{array}$ & $\begin{array}{l}\text { granulomatous } \\
\text { hepatitis }\end{array}$ & 4 week & 1 week & $\begin{array}{l}\text { (Offit et } \\
\text { al.,1984) }\end{array}$ \\
\hline 3. & $\begin{array}{l}77 \text { year old with } \\
\text { peptic ulcer disease. }\end{array}$ & $\begin{array}{l}150 \mathrm{mg} \\
\text { twice daily }\end{array}$ & $\begin{array}{l}\text { Elevated ALT ad alkaline phosphatase } \\
\text { (ALK P) }\end{array}$ & $\begin{array}{l}\text { liver biopsy } \\
\text { showing focal } \\
\text { necrosis }\end{array}$ & 3 days & 2weeks & $\begin{array}{l}\text { (Souza et al., } \\
1984)\end{array}$ \\
\hline 4. & $\begin{array}{l}58 \text { year old man } \\
\text { with duodenal ulcer }\end{array}$ & $\begin{array}{l}150 \mathrm{mg} \\
\text { daily }\end{array}$ & $\begin{array}{l}\text { mild elevations in serum alanine } \\
\text { aminotransferase (ALT) and alkaline } \\
\text { phosphatase. }\end{array}$ & $\begin{array}{l}\text { cholestatic } \\
\text { hepatitis and } \\
\text { jaundice }\end{array}$ & 2 weeks & 4 weeks & $\begin{array}{l}\text { (Devuyst et al., } \\
1993)\end{array}$ \\
\hline 5. & $\begin{array}{l}29 \text { year old man } \\
\text { with symptoms of } \\
\text { gastroesophageal } \\
\text { reflux. }\end{array}$ & $\begin{array}{l}150 \mathrm{mg} \\
\text { twice daily }\end{array}$ & $\begin{array}{l}\text { marked elevations in serum bilirubin, mild } \\
\text { elevation in serum aminotransferase and } \\
\text { ALK P. }\end{array}$ & $\begin{array}{l}\text { Bland } \\
\text { cholestasis }\end{array}$ & 2 weeks & 2-3 month & $\begin{array}{l}\text { (Ramrakhiani } \\
\text { et al., 1998) }\end{array}$ \\
\hline 6. & 73 year old & $\begin{array}{l}150 \mathrm{mg} \\
\text { twice daily }\end{array}$ & $\begin{array}{l}\text { hyperbilirubinemia }(15.6 \mathrm{mg} / \mathrm{dL}) \text { with } \\
\text { conjugated bilirubin, a } 2.5 \text {-fold elevation } \\
\text { of alkaline phosphatase and moderate } \\
\text { increase in aspartate aminotransferase and } \\
\text { alanine aminotransferase. }\end{array}$ & $\begin{array}{l}\text { diffuse } \\
\text { canalicular } \\
\text { cholestasis }\end{array}$ & 3 weeks & 50 days & $\begin{array}{l}\text { (Liberopoulos } \\
\text { et al., 2002) }\end{array}$ \\
\hline
\end{tabular}




\section{History of Ranitidine Associated Toxicity}

Ranitidine was first introduced by john Bradshaw in the UK as AH19065 in 1977 at the Ware research laboratories of Allen and Hanburys, division of a larger Glaxo organization (Lednicer, 1993). Further it was developed by Sir James Black at Smith, Kline and French in response to the first H2-receptor, antagonist, launched as Tagamet on November 1976 in United Kingdom. Furthermore, Glaxo developed the model with modification to the structure to nitrogen containing substituent, i.e. substituting the cimetidine imidazole ring with a furan ring and creating ranitidine. The tolerance level of RAN (i.e. fewer adverse reactions) was said to be much better and more powerful than cimetidine. RAN has about $10 \%$ interaction with cytochrome P 450 which indicates fewer side effects, but there are no major interactions with cytochrome $\mathrm{P} 450$ and other $\mathrm{H} 2$ blockers, such as nizatidine and famotidine (Newhouse, 1986). Ranitidine was the newly introduced and a United States Food and Drug Administration (US-FDA) approved H2 receptor antagonist for short-term oral use in duodenal ulcer therapy and in the Zollinger-Ellison syndrome in hypersecretory states (Med Lett, 1982). Few reports of clinical hepatotoxicity have been reported in Europe, Australia and Canada while undergoing oral preparation therapy and symptomatic liver disease have occurred in the United States during treatment with oral ranitidine (Barr, 1981; Cleator, 1983). A study showed that patients had symptomatic liver disease between 3 and 5 weeks after the ranitidine treatment, concerned symptoms like headache, "flu-like symptoms" (shaking chills and fever) and dark urine had also been observed for one day (Black et al., 1984).
Recently, on April 1, 2020, the presence of contaminants was recognized as N-Nitrosodimethylamine (NDMA), the US-FDA immediately demanded the manufacturers for withdrawal of all the over-the-counter (OTC) and prescription RAN products. However in some of the samples, the US-FDA failed to detect inappropriate NDMA levels, they found that the contamination of some ranitidine products increased over the course of the time, when stored at higher room temperatures. As a consequence, ranitidine products are banned for use in the US (Lim et al., 2020). NDMA (a cancer causative agent) is a possible human carcinogen, and low NDMA levels are normally consumed in diets. These levels, do not contribute to rise in cancer risk. The US-FDA conducted comprehensive testing on ranitidine and found a very low level of NDMA and suggested to avoid the use of Ranitidine products. In September 2019, the US-FDA concluded its analysis and informed the people about possible hazards and proposed alternative OTC and prescription therapies (Francis et al., 2005).

\section{Molecular Mechanism Involved in Ranitidine Associated Hepatotoxicity}

It is believed that RAN induced hepatotoxicity involves two pathways i.e. Immune mediated (Immunoallergic reactions) and direct cellular dysfunction. Though, the exact mechanism behind ranitidine induced hepatotoxicity still remains unclear (Bleibel et al., 2007), a schematic diagram concerned with the possible mechanism of RAN induced hepatotoxicty has been hypothesized in Figure 1.



Figure 1: Illustration of pathways involved in ranitidine induced liver injury/ hepatotoxicity. 


\subsection{Immune-Mediated Liver Injury (Immunoallergic reactions)}

The liver contains abundant sinusoidal macrophages i.e. Kupffer cells, which are responsible for the removal of foreign antigens, cellular debris and waste via hepatic portal system. It promotes the activation of cytotoxic $\mathrm{T}$ cells and induces apoptotic death of activated $\mathrm{T}$ cells and suppresses the immune response against these foreign antigens thereby increase immune tolerance (Maddrey et al., 2005). In case of ranitidine associated liver injury this process gets disrupted and results in impaired immune tolerance and generate altered autoantigens (Bleibel et al., 2007). These autoantigens binds to the surface of B-cells and forms MHC type I with hepatocytes via antigen-antibody reaction which subsequently causes induction of autoimmune reactions or antibody dependent immune response or B-cell mediated humoral response which is responsible for cellular destruction of hepatocytes via phagocytosis (Bleibel et al., 2007). In addition, these cellular immune responses triggers the release of pro-inflammatory mediators and various cytokines such as Tumour Necrosis Factor $\alpha(\mathrm{TNF} \alpha)$, nitrogen oxide $(\mathrm{NO})$, FasL, and various interferons particularly IFN- $\gamma$ (Kaplowitz et al., 2004).

\subsection{Direct Cellular Damage}

In majority of cases, RAN induced liver injury is triggered by chemically active toxic metabolite of drug which binds to cellular components such as lipids, proteins, nucleic acids and other cellular organelles leading to direct cellular dysfunction such as altered protein synthesis, nuclear damage and lipid peroxidation, which subsequently increases mitochondrial oxidative stress and promotes hepatocellular damage (Holt et al., 2006). Additionally, this direct cellular damage also increases the sensitivity of cells to the TNF receptor (Particularly TNFo) which triggers apoptotic cascade activation and induces apoptosis and promotes phagocytosis by the activation of cytotoxic T-cells (CD8) and leads to necrotic or apoptotic damage of hepatocytes. There is lot of phenotypic genetic variation amongst people; some people are vulnerable to RAN associated idiosyncratic reactions, whereas some are resistant. The microsomal P450 is responsible for the metabolism of RAN. Patients who lack cytochrome P450 enzyme are more prone to idiosyncratic reactions, because in the absence of cytochrome P450, metabolism of ranitidine is affected which leads to formation of its toxic metabolites and various intermediates which are responsible for hepatocellular damage (Kaplowitz et al., 2004).

\section{Case Study Reports on Ranitidine Therapy}

Ranitidine has been used for years in the treatment of gastrointestinal diseases and considered as the most prescribed drugs in the world. As DILIs are generally idiosyncratic, infrequent and unpredictable therefore difficult to induce in animal models therefore, either no or very fewer preclinical models have been developed for idiosyncratic DILI which makes it difficult to understand its exact pathogenesis (Chalasani et al., 2010). A few case studies have been tabulated in Table 2 .

\section{Steps Taken by Government and Any Regulations}

US-FDA, European Medicines Agency (EMA), and Central Drugs Standard Control Organisation (CDSCO) have spotted the stringent content of nitrosamine in various products of RAN (Shaik et al., 2020). India's drug regulatory authority has ordered to withdraw samples of RAN, after the US regulator declared the presence of a cancer-causing impurity in some products (Woodcock, 2019). The Drug Controller General of India (DCGI) has asked the state drug regulators to withdraw all the samples of RAN from the major manufacturers and send those to Central Drug Laboratory (CDL) in Kolkata in order to test the impurity i.e. N-Nitrosodimethylamine (NDMA). Meanwhile, the appellate laboratory in Kolkata may not have the equipment to conduct the Liquid ChromatographyHigh Resolution Mass Spectrometry (LC-HRMS) test which has been recommended by the US-FDA for testing NDMA in ranitidine products. Venues have now been explored to get these tests done by private analytical laboratories. The US-FDA has released an update on NDMA testing for ranitidine, which warns manufacturers that they should not perform the aforementioned test in high-temperature because they produce high impurities for the presence of NDMA (Teena Thacker, 2019). In India, GSK agreed to withdraw all dosage forms of ranitidine hydrochloride from the market due to the pending outcome of ongoing tests and investigations as a precautionary action in correspondence with regulatory authorities (The Hindu, 2019).

\section{Conclusion}

RAN induced liver injury is difficult to diagnose and study because of its relative rarity and unpredictive occurrence (Watkins et al., 2005). Recent studies suggest that most of the RAN associated idiosyncratic reactions may lead to hepatocyte damage, followed by a series of events, such as activation of specific T-and B-cells, release of proinflammatory mediators like TNF $\alpha$, interleukins, various cytokines and chemokines. However RAN induced hepatotoxicity is selflimiting in majority of cases, if early diagnosis is not made, then it may develop into severe hepatic failure (Rashid et al., 2004). In a preclinical study, it was observed that ranitidine 
$(30 \mathrm{mg} / \mathrm{kg})$ did not produce liver injury in healthy animals; it was hepatotoxic in only those rats which are having mild inflammatory response induced by LPS (Luyendyk et al., 2003). The liver injury caused by RAN is usually rapidly reversible with cessation of the treatment. Gastroenterologists must be aware of the consequences before prescribing RAN to the patients who are already suffering from any liver diseases. The exact cause of RAN associated idiosyncratic hepatotoxicity is not clear yet. However, some studies suggest that the $\mathrm{H} 2$ receptor antagonists may be a potential cause for idiosyncratic hepatotoxic reactions; therefore it is not prescribed now-a-days. Due to the lack of preclinical and clinical studies on RAN associated liver injury, it is difficult to conclude the exact pathogenesis and the possible ADRs. However, Nitrosamines are genotoxic impurities, and due to their carcinogenicity, they pose an alarming threat to all creatures of earth. To alleviate this global issue, regulatory agencies such as CDSCO, US-FDA, and EMA have given their continuous effort for quantitative determination of amine impurities present in food stuffs, and in various intermediates in organic synthesis (Shaik et al., 2020). More studies must be carried out on this to know about the reason behind its hepatotoxicity.

\section{Future Prospective}

It is a topic of debate among various academicians and scientists "whether ranitidine will be available again in future or will FDA withdraw approvals of ranitidine (NDA) and An abbreviated new drug application (ANDA)?" However USFDA detected NDMA as a carcinogenic impurity still they failed to detect the optimum level or concentration at which it may harm the liver and other vital organs. There can be a possibility that RAN will come again in the market if the level of NDMA is found negligible or harmless concerned regarding patients health. There is a need to carry out more experimental studies in order to detect the optimum level of NDMA which is ultimately causing RAN associated hepatotoxicity.

\section{Competing interests}

The authors declare that they have no competing interests.

\section{Availability of Data and Materials}

Data and material regarding the material reported as selfcitation by the authors in this Mini-review is available upon request.

\section{Consent for Publication}

All are aware of its submission to the Journal and its publication.

\section{Ethics Approval and Consent to Participate}

There are no mandatory ethics documents associated with this mini review report.

\section{Acknowledgements}

We acknowledge the Chitkara University for providing facilities and continuous support for writing this review article.

\section{Abbreviations}

ADR: Adverse drug reactions; ALK P: Alkaline phosphatase; ALP: Alanine phosphatase; ALT: Alanine aminotransferase; ANDA: An abbreviated new drug application; AST: Aspartate aminotransferase; CDCSO: Central Drugs Standard Control Organisation; CDL: Central Drug Laboratory; DCGI: Drug Controller General of India; DILI: Drug induced liver injury; EMA: European Medicines Agency; GGT: Gamma-glutamyl transpeptidase; H2: Type-2 histamine; IADRs: idiosyncratic adverse drug reactions; IFN: Interferon; LC-HRMS: Liquid Chromatography-High Resolution Mass Spectrometry; LPS: Lipopolysaccharides; NDA: New Drug Application; NDMA: N-Nitrosodimethylamine; NK: Natural killer cells; NKT: Natural killer T cells; NO: Nitrogen oxide; OTC: Over-the-counter; PMS: Post-marketing surveillance; RAN Ranitidine; TNF: Tumour necrosis factor; US-FDA: United States Food and drug administration.

\section{References}

Alfirevic, A., \& Pirmohamed, M. (2012). Predictive genetic testing for drug-induced liver injury: considerations of clinical utility. Clin Pharmacol Ther., 92(3), 376-380. https://doi.org/10.1038/clpt.2012.107

Barr, G.D., \& Piper, D.W. (1981). Possible ranitidine hepatitis. Medical Journal of Australia, 2(8), 421. https://doi.org/10.5694/j.1326-5377.1981. tb101036.x

Berson, A., Descatoire, V., Sutton, A., Fau, D., Maulny, B., Vadrot, N., Feldmann, G., Berthon, B., Tordjmann, T., \& Pessayre, D. (2001). Toxicity of alpidem, a peripheral benzodiazepine receptor ligand, but not zolpidem, in rat hepatocytes: role of mitochondrial permeability transition and metabolic activation. The Journal of Pharmacology and Experimental Therapeutics, 299(2), 793-800.

Black, M., Scott, W.E., \& Kanter, R. (1984). Possible ranitidine hepatotoxicity. Annals of Internal Medicine, 101(2), 208-210. https://doi.org/10.7326/00034819-101-2-208

Blazka, M.E., Elwell, M.R., Holladay, S.D., Wilson, R.E., \& Luster, M.I. (1996). Histopathology of acetaminophen- 
induced liver changes: role of interleukin $1 \alpha$ and tumor necrosis factor $\alpha$. Toxicologic Pathology, 24(2), 181189. https://doi.org/10.1177/019262339602400206

Blazka, M.E., Wilmer, J.L., Holladay, S.D., Wilson, R.E., \& Luster, M.I. (1995). Role of proinflammatory cytokines in acetaminophen hepatotoxicity. Toxicology and Applied Pharmacology, 133(1), 43-52. https://doi. org/10.1006/taap.1995.1125

Bleibel, W., Kim, S., D’Silva, K., \& Lemmer, E.R. (2007). Drug-induced liver injury. Digestive Diseases and Sciences, 52(10), 2463-2471. https://doi.org/10.1007/ s10620-006-9472-y

Chalasani, N., \& Björnsson, E. (2010). Risk factors for idiosyncratic drug-induced liver injury. Gastroenterology, 138(7), 2246-2259. https://doi. org/10.1053/j.gastro.2010.04.001

Cleator, I.G. (1983). Adverse effects of ranitidine therapy. Canadian Medical Association Journal, 129(5), 405b405.

Devuyst, O., Lefebvre, C., Geubel, A., \& Coche, E. (1993). Acute cholestatic hepatitis with rash and hypereosinophilia associated with ranitidine treatment. Acta Clinica Belgica, 48(2), 109-114. https://doi.org/1 $0.1080 / 17843286.1993 .11718294$

Drug regulator cautions against over-the-counter use of ranitidine. (2019, September 25). The Hindu. https:// www.thehindu.com/news/national/drug-regulatorcautions-against-over-the-counter-use-of-ranitidine/ article29511521.ece

Fagius, J., Osterman, P.O., Siden, A., \& Wiholm, B.E. (1985). Guillain-Barré syndrome following zimeldine treatment. Journal of Neurology, Neurosurgery and Psychiatry, 48(1), 65-69. https://doi.org/10.1136/ jnnp.48.1.65

Francis, S.-A., Barnett, N., \& Denham, M. (2005). Switching of prescription drugs to over-the-counter status. Drug Aging, 22(5), 361-370. https://doi. org/10.2165/00002512-200522050-00001

Fung, M., Thornton, A., Mybeck, K., Wu, J.H.-H., Hornbuckle, K., \& Muniz, E. (2001). Evaluation of the characteristics of safety withdrawal of prescription drugs from worldwide pharmaceutical markets-1960 to 1999. Drug information journal : DIJ / Drug Information Association, 35(1), 293-317. https://doi. org/10.1177/009286150103500134

Holt, M.P., \& Ju, C. (2006). Mechanisms of drug-induced liver injury. The AAPS Journal, 8(1), E48-E54. https:// doi.org/10.1208/aapsj080106

Ishida, Y., Kondo, T., Ohshima, T., Fujiwara, H., Iwakura, Y., \& Mukaida, N. (2002). A pivotal involvement of IFN-' in the pathogenesis of acetaminophen-induced acute liver injury. The FASEB Journal, 16(10), 12271236. https://doi.org/10.1096/f.02-0046com

Kaplowitz, N. (2004). Drug-induced liver injury. Clinical Infectious Diseases, 38(Supplement_2), S44-S48. https://doi.org/10.1086/381446

Kaplowitz, N. (2005). Idiosyncratic drug hepatotoxicity. Nature Reviews Drug Discovery, 4(6), 489-499. https:// doi.org/10.1038/nrd1750

Lednicer, D. (Eds.) (1993). Chronicles of drug discovery. (Vol. 3). American Chemical Society: Washington D.C.

Liberopoulos, E.N., Nonni, A.B., Tsianos, E.V., \& Elisaf, M.S. (2002). Possible ranitidine-induced cholestatic jaundice. Annals of Pharmacotherapy, 36(1), 172. https://doi.org/10.1345/aph.10420

Lim, H.-H., Oh, Y.-S., \& Shin, H.S. (2020). Determination of $\mathrm{N}$-nitrosodimethylamine and $\mathrm{N}$-nitrosomethylethylamine in drug substances and products of sartans, metformin and ranitidine by precipitation and solid phase extraction and gas chromatography-tandem mass spectrometry. Journal of Pharmaceutical and Biomedical Analysis, 189, 113460. https://doi.org/10.1016/j.jpba.2020.113460

Luyendyk, J.P., Lehman-McKeeman, L.D., Nelson, D.M., Bhaskaran, V.M., Reilly, T.P., Car, B.D., Cantor, G.H., Maddox, J.F., Ganey, P.E., \& Roth, R.A. (2006). Unique gene expression and hepatocellular injury in the lipopolysaccharide-ranitidine drug idiosyncrasy rat model: Comparison with famotidine. Toxicological Sciences, 90(2), 569-585. https://doi.org/10.1093/toxsci/kf103

Maddrey, W.C. (2005). Drug-induced hepatotoxicity: 2005. Journal of Clinical Gastroenterology, 39(4), S83-S89. https://doi.org/10.1097/01.mcg.0000155548.91524.6e

Schubert-Zsilavecz, M. (2011). Drug withdrawals Recall in review. Pharmazeutische Zeitung. Retrieved from https://www.pharmazeutische-zeitung.de/index. php?id $=38778$

Newhouse, K.E. (1986). Goodman and Gilman's The Pharmacological Basis of Therapeutics. Yale Journal of Biology and Medicine, 59(1), 71-72.

Offit, K., \& Sojka, D.A. (1984). Ranitidine. New England Journal of Medicine, 310, 1601-1606. https://doi. org/10.1056/NEJM198406143102413

Pemoline. Drug Bank. Retrieved on July 20, 2020, from https://web.archive.org/web/20130927055300/ http://www.drugbank.ca/drugs/DB01230

Qureshi, Z.P., Seoane-Vazquez, E., Rodriguez-Monguio, R., Stevenson, K.B., \& Szeinbach, S.L. (2011). Market withdrawal of new molecular entities approved in the United States from 1980 to 2009. Pharmacoepidemiology and Drug Safety, 20(7), 772777. https://doi.org/10.1002/pds.2155 
Ramrakhiani, S., Brunt, E.M., \& Bacon, B.R. (1998). Possible cholestatic injury from ranitidine with a review of the literature. The American Journal of Gastroenterology, 93(5), 822-826. https://doi. org/10.1111/j.1572-0241.1998.233_a.x

Ranitidine (ZANTAC). (1982). The Medical Letter on Drugs and Therapeutics, 24(625), 111-113.

Rashid, M., Goldin, R., \& Wright, M. (2004). Drugs and the liver. Hospital Medicine, 65(8), 456-461. https:// doi.org/10.12968/hosp.2004.65.8.15489

Shaik, K.M., Sarmah, B., Wadekar, G.S., \& Kumar, P. (2020). Regulatory Updates and Analytical Methodologies for Nitrosamine Impurities Detection in Sartans, Ranitidine, Nizatidine, and Metformin along with Sample Preparation Techniques. Critical Reviews in Analytical Chemistry, 1-9. https://doi.org/1 0.1080/10408347.2020.1788375

Souza lima, M.A. (1984). Hepatitis associated with ranitidine. Annals of Internal Medicine, 101(2), 207208. https://doi.org/10.7326/0003-4819-101-2-207

Stepan, A.F., Walker, D.P., Bauman, J., Price, D.A., Baillie, T.A., Kalgutkar, A.S., \& Aleo, M.D. (2011). Structural alert/reactive metabolite concept as applied in medicinal chemistry to mitigate the risk of idiosyncratic drug toxicity: a perspective based on the critical examination of trends in the top
200 drugs marketed in the United States. Chemical Research in Toxicology, 24(9), 1345-1410. https://doi. org/10.1021/tx200168d

Thacker, T. (2019, October 14). Drug regulator steps up monitoring of ranitidine. The Economic Times. Retrieved from https://economictimes.indiatimes. com/industry/healthcare/biotech/pharmaceuticals/ drug-regulator-steps-up-monitoring-of-ranitidine/ articleshow/71573124.cms?from $=\mathrm{mdr}$

Teschke, R., \& Danan, G. (2018). Drug induced liver injury with analysis of alternative causes as confounding variables. British Journal of Clinical Pharmacology, 84(7), 1467-1477. https://doi.org/10.1111/bcp.13593

Watkins, P.B. (2005). Idiosyncratic liver injury: challenges and approaches. Toxicologic Pathology, 33(1), 1-5. https://doi.org/10.1080/01926230590888306

European Medicines Agency (2018). Withdrawal of pain medicine flupirtine endorsed. Retrieved from https:// www.ema.europa.eu/en/news/withdrawal-painmedicine-flupirtine-endorsed

Woodcock, J. (2019). Statement on new testing results, including low levels of impurities in ranitidine drugs. Retrieved from https://www.fda.gov/news-events/ press-announcements/statement-new-testing-resultsincluding-low-levels-impurities-ranitidine-drugs

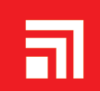 CHITKARA}

\section{Journal of Pharmaceutical Technology, Research and Management}

Chitkara University, Saraswati Kendra, SCO 160-161, Sector 9-C, Chandigarh, 160009, India

Volume 8, Issue 1

May 2020

ISSN 2321-2217

Copyright: [C2020 Amit Bandyopadhyay Banerjee et al.] This is an Open Access article published in Journal of Journal of Pharmaceutical Technology, Research and Management (J. Pharm. Tech. Res. Management) by Chitkara University Publications. It is published with a Creative Commons Attribution- CC-BY 4.0 International License. This license permits unrestricted use, distribution, and reproduction in any medium, provided the original author and source are credited. 